\title{
Sukupuolivähemmistöjen informaatiokäyttäytyminen
}

\author{
Aira Huttunen \\ Oulun yliopisto \\ aira.huttunen@oulu.fi
}

Väitöskirjatyöni käsittelee sukupuolivähemmistöjen informaatiokäyttäytymistä. Se kuuluu tietokäyttäytymisen piiriin ja tuottaa uutta tietoa sukupuolivähemmistöihin kuuluvien ihmisten informaatiokäyttäytymisestä. Sukupuolivähemmistöihin kuuluvat transihmiset (transsukupuoliset, transvestiitit, muunsukupuoliset) sekä intersukupuoliset. Tutkimusmenetelminä käytän sekä määrällisiä että laadullisia aineistonkeruumenetelmiä: kyselyä ja teemahaastattelua. Laadullisen aineiston analyysimenetelmänä käytän sisällönanalyysia.

Sukupuolivähemmistöihin kuuluvat ihmiset, joiden psykologisen ja biologisen sukupuolen välillä on jonkinlainen ristiriita, tai jotka eivät ole yksiselitteisesti miehiä tai naisia. Transsukupuolisella tarkoitetaan ihmistä, jonka sukupuoliidentiteetti, sukupuolen ilmaisu tai käyttäytyminen ei vastaa sitä sukupuolta, johon hänet on syntymässä määritetty ja hän saattaa haluta korjata fyysisen sukupuolensa vastaamaan kokemaansa sukupuolta sukupuolenkorjaushoitojen avulla. Muunsukupuolinen ei halua tulla määritellyiksi mieheksi tai naiseksi, ja kokee olevansa jotakin siltä väliltä, sukupuoleltaan määrittelemätön tai sukupuoleton. Transvestiitti haluaa eläytyä toiseen sukupuoleen esimerkiksi pukeutumisen avulla. (Veale, Lomax, \& Clarke, 2010, s. 125.) Intersukupuolisten anatomis-fysiologiset ominaisuudet eivät ole selkeästi ja yhtenäisesti miehen tai naisen, vaan heillä on synnynnäisesti miehen ja naisen sukupuoliominaisuuksia. Suomessa arvioidaan olevan 5000 transsukupuolista ja noin 50 000-100 ooo transvestiittia. Vuosittain Suomessa syntyy 5-20 intersukupuolista, mutta 
yksiselitteistä tietoa näistä määristä ei ole Suomessa eikä maailmanlaajuisesti. (Tasa-arvovaltuutetun toimisto, 2012, ss. 7-9.)

Väitöskirjan tärkein teoriatausta koostuu Chatmanin (1991, 1999) pientä maailmaa ja informaation vaikuttavuutta koskevista teorioista, joissa informaation niukkuus ja vähemmistöryhmät ovat keskiössä. Chatmanin teorioita on hyödynnetty aiemmin esimerkiksi seksuaalivähemmistöjä koskevassa tutkimuksessa (ks. Hamer, 2003; Veinot, Meadowbrooke, Loveluck, Hickok, \& Bauermeister, 2013). Tutkimuksessa hyödynnetään myös tiedonhankinnan ja siihen liittyvien esteiden malleja (esim. Williamson, 2005; Wilson \& Walsh, 1996).

Väitöskirjatutkimukseni tuloksista on käytännön hyötyä tiedon tuottajille tiedon kohdentamisessa ja rääälöimisessä (ks. esim. Enwald, 2013), jolloin sukupuolivähemmistöjen tiedontarpeisiin voidaan vastata paremmin. Tutkimus myös tekee sukupuolivähemmistöt näkyvämmäksi yhteiskunnassa ja tarjoaa lisätietoa marginalisoiduista ihmisistä, jotka ovat vain harvoin esillä mediassa ja tutkimuksissa. Tässä tutkimuksessa asetetaan seuraavat tutkimuskysymykset:

1. Millaista sukupuolivähemmistöjen omaan identiteettiin liittyvä informaatiokäyttäytyminen on?

2. Mitkä tekijät vaikuttavat sukupuolivähemmistöjen tiedonhankintaan? Mitkä asiat helpottavat ja mitkä estävät tiedonhankintaa?

3. Millä tavalla kehollisuus liittyy sukupuolivähemmistöihin kuuluvien ihmisten tiedon tarpeisiin ja tiedon saamiseen? Tuottaako oma keho tietoa omasta sukupuolikokemuksesta ja jos tuottaa, millaista tietoa?

4. Vaikuttaako stigmatisoitumisen pelko sukupuolivähemmistöjen tiedonhankintaan ja jos vaikuttaa, millä tavalla?

Väitöskirjani koostuu osatöistä, joiden tulokset esitellään tieteellisissä lehdissä julkaistavissa neljässä artikkelissa. Ensimmäinen osatyö on artikkeli "Transgender information behaviour", joka julkaistiin Journal of Documentation lehdessä vuonna 2016, joka on kirjoitettu pro gradu -työni pohjalta. Väitöskirjaani kuuluvien seuraavien osatutkimusten esiymmärrys perustuu ensimmäisen artikkelini havaintoihin. Väitöskirjani esiymmärryksenä on, että sukupuolivähemmistöihin kuuluvilla ihmisillä on sukupuoli-identiteettiin liittyviä tiedontarpeita ja he ovat yrittäneet löytää tietoa, joka voisi auttaa heitä rakentamaan omaa sukupuoli-identiteettiään.

Toinen osatyö on määrällinen, ja siinä tutkitaan sukupuolivähemmistöihin kuuluvien ihmisten tiedonhankintaan vaikuttavia esteitä ja mahdollistavia tekijöitä. Toisen osatyön aineistona käytetään tekemäni kyselyn tuloksia. Aineisto sisältää 162 sukupuolivähemmistöön kuuluvan ihmisen vastaukset Internet- 
kyselyyn, joka käsitteli tiedonhankintaa, siihen vaikuttavia tekijöitä sekä tiedonlähteitä.

Kolmas osatyö on laadullinen, ja se käsittelee sukupuolivähemmistöihin kuuluvien ihmisten kehollisuutta sekä kehoa tiedon lähteenä. Kolmannen osatyön aineistona käytetään keräämääni haastatteluaineistoa. Haastattelin 25:tä sukupuolivähemmistöön kuuluvaa ihmistä kevälllä ja kesällä 2016. Tätä samaa haastatteluaineistoa hyödynnetään myös neljännessä osatyössä, joka käsittelee sukupuolivähemmistöihin kohdistuvaa stigmaa ja stigmatisoitumisen pelkoa tiedonhankinnan kontekstissa. Kaiken kaikkiaan nämä neljä osatyötä antavat monipuolisen kuvan sukupuolivähemmistöjen informaatiokäyttäytymisestä.

\section{Lähteet}

Chatman, E. A. (1991). Life in a small world: Applicability of gratification theory to informationseeking behavior. Journal of the American Society for Information Science, 42(6), 438-449. https://doi.org/10.1002/(SICI)1097-4571(199107)42:6<438::AID-ASI6>3.0.CO;2-B

Chatman, E. A. (1999). A theory of life in the round. Journal of the American Society for Information Science, 50(3), 207-217. https://doi.org/10.1002/(SICI)1097-4571(1999)50:3<207::AID$\mathrm{ASI}_{3}>3.0 . \mathrm{CO} ; 2-8$

Enwald, H. (2013). Tailoring health communication : the perspective of information users' health information behaviour in relation to their physical health status (Doctoral Dissertation). University of Oulu. http://urn. fi/urn:isbn:9789526202792

Hamer, J. S. (2003). Coming-Out: Gay Males' Information Seeking. School Libraries Worldwide; Edmonton, 9(2), 73-89.

Tasa-arvovaltuutetun toimisto. (2012). Selvitys sukupuolivähemmistöjen asemasta (Vsk. 2012). Helsinki: Sosiaali- ja terveysministeriö. http://urn.fi/URN:NBN: fi-fe201504224662

Veale, J. F., Lomax, T., \& Clarke, D. (2010). Identity-Defense Model of Gender-Variant Development. International Journal of Transgenderism, 12(3), 125-138. https://doi .org/10.1080/ 15532739.2010 .514217

Veinot, T. C., Meadowbrooke, C. C., Loveluck, J., Hickok, A., \& Bauermeister, J. A. (2013). How "Community" Matters for How People Interact With Information: Mixed Methods Study of Young Men Who Have Sex With Other Men. Journal of Medical Internet Research, 15(2). https://doi.org/10.2196/jmir.2370

Williamson, K. (2005). Ecological theory of human information behavior. Teoksessa K. E. Fisher, S. Erdelez, \& L. E. McKechni (toim.), Theories of Information Behavior (ss. 128-132). Medford, N.J.: Information Today.

Wilson, T. D., \& Walsh, C. (1996). Information behaviour: An inter-disciplinary perspective: A review of the literature. London: British Library Research and Innovation Centre. 